\title{
RESPON TANAMAN KEDELAI (Glycine max L. Merril) TERHADAP PUPUK ANORGANIK PADA BERBAGAI MASUKAN ENERGI JUMLAH PANAS
}

\author{
Oleh: Perdian Syaputra**Ir. Suryadi, MP dan Ir. Usman, M.Si \\ (Alumni FP UMB dan **dosen FP UMB)
}

\begin{abstract}
ABSTRAK
Respon Tanaman Kedelai (Glycine max L. Merril) Terhadap Pupuk Anorganik Pada Berbagai Masukan Energi Jumlah Panas (MEJP). Mahasiswa Agroteknologi Fakultas Pertanian dan Peternakan Universitas Muhammadiyah Bengkulu. Di bawah bimbingan Ir. Suryadi, MP. sebagai pembimbing utama dan Ir. Usman, M.Si. sebagai pembimbing kedua. Tujuan penelitian ini adalah untuk mengetahui Respon Tanaman Kedelai (Glycine max L. Merril) Terhadap Pupuk Anorganik Pada Berbagai Masukan Energi Jumlah Panas (MEJP). Rancangan yang digunakan menggunakan rancangan acak lengkap (RAL) faktorial dengan 2 faktor yaitu faktor pertama Masukan Energi Jumlah Panas (M) : M1 (1030-1050 SP), M2 (1130-1150), M3 (1230-1250), M4 (1330-1350), sedangkan faktor kedua Pupuk Anorganik (B) : B1 $(12,5 \mathrm{~kg} \mathrm{Urea} / \mathrm{ha}+100 \mathrm{~kg} \mathrm{SP}-36 / \mathrm{ha}+50 \mathrm{~kg} \mathrm{KCl} / \mathrm{ha}), \mathrm{B} 2(25 \mathrm{~kg}$ Urea/ha $+50 \mathrm{~kg} \mathrm{SP}-36 / \mathrm{ha}+50 \mathrm{~kg}$ $\mathrm{KCl} / \mathrm{ha})$, B3 (25 kg Urea/ha $+100 \mathrm{~kg} \mathrm{SP}-36 / \mathrm{ha}+25 \mathrm{~kg} \mathrm{KCl} / \mathrm{ha})$ masing-masing perlakuan diulang sebanyak 3 kali.

Hasil data dianalisis menggunakan Analisis Sidik Ragam (ANOVA) dan apabila berbeda nyata dilakukan uji lanjut Duncan's Multiple Range Test (DMRT) taraf $5 \%$. Hasil penelitian menunjukan bahwa Masukan Energi Jumlah Panas tidak berpengaruh nyata terhadap semua pengamatan tanaman kedelai (Glycine max L. Merril). Sedangkan Pupuk Anorganik berpengaruh nyata terhadap Jumlah Polong dan Jumlah Biji tanaman kedelai (Glycine max L. Merril). Dan terjadi interaksi antara Masukan Energi Jumlah Panas dan Pupuk Anorganik terhadap Berat Kering Tanaman kedelai (Glycine max L. Merril).
\end{abstract}

Kata kunci : kedelai, masukan energi jumlah panas, pupuk anorganik

\begin{abstract}
Response of Soybean Plants (Glycine max L. Merril) Against Inorganic Fertilizers at Various Energy Inputs of Total Heat (MEJP). Agrotechnology student, Faculty of Agriculture and Animal Husbandry, Muhammadiyah Bengkulu University. Under the guidance of Ir. Suryadi, MP. as the main supervisor and Ir. Usman, M.Si. as the second mentor. The purpose of this study was to determine the response of Soybean (Glycine max L. Merril) to Inorganic Fertilizers at Various Energy Inputs of Total Heat (MEJP). The design used was a factorial completely randomized design (CRD) with 2 factors, namely the first factor: Energy Input Total Heat (M): M1 (1030-1050 SP), M2 (1130-1150), M3 (12301250), M4 (1330 -1350), while the second factor of Inorganic Fertilizer (B): B1 (12.5 kg Urea / ha + 100 $\mathrm{kg} \mathrm{SP}-36 / \mathrm{ha}+50 \mathrm{~kg} \mathrm{KCl} / \mathrm{ha}), \mathrm{B} 2$ (25 kg Urea / ha + $50 \mathrm{~kg} \mathrm{SP}-36 / \mathrm{ha}+50 \mathrm{~kg} \mathrm{KCl} / \mathrm{ha}), \mathrm{B} 3$ (25 kg Urea / ha $+100 \mathrm{~kg} \mathrm{SP}-36 / \mathrm{ha}+25 \mathrm{~kg} \mathrm{KCl} / \mathrm{ha}$ ) each treatment was repeated 3 times.

The results of the data were analyzed using Analysis of Variance (ANOVA) and if they were significantly different, a 5\% level of Duncan's Multiple Range Test (DMRT) was continued. The results showed that the energy input of the amount of heat had no significant effect on all observations of soybean (Glycine max L. Merril). Meanwhile, inorganic fertilizers significantly affected the number of pods and the number of soybean seeds (Glycine max L. Merril). And there is an interaction between the energy input of the amount of heat and inorganic fertilizers on the dry weight of soybean plants (Glycine max L. Merril).
\end{abstract}

Key words: soybean, heat input, inorganic fertilizer 


\section{BAB I}

\section{PENDAHULUAN}

\subsection{Latar Belakang}

Tanaman pangan yang dapat memenuhi dan meningkatkan gizi bagi masyarakat salah satunya adalah tanaman dari jenis kacang-kacangan yaitu tanaman kedelai (Ridwan, Hidayat, Kushendarto dan Sunyoto, 2017). Kadar protein kacang-kacangan berkisar antara 20-25 \% sedangkan pada kedelai mencapai $40 \%$ (Winarsi, 2010). Selain itu juga protein pada kedelai juga lebih tinggi daripada daging, kandungan protein pada daging hanya berkisar $17,5 \%$. Tidak hanya protein saja yang terkandung dalam kedelai, menurut Podesta (1997) dan Amanda (2008) setiap 100 gr biji kedelai mengandung 18 gr lemak, 35 gr karbohidrat, 35-40 gr protein, 8 gr air, 330 kalori, 227 mgr kalsium, 585 mgr fosfor, 8 gr besi, vitamin A dan 1 mgr vitamin B1. Kedelai sangat tepat menjadi pilihan untuk asupan protein, karena selain kandungan proteinnya yang lebih tinggi dari daging, harganya juga sangat terjangkau daripada harus membeli daging yang harganya kian mahal.

Permintaan kedelai di Indonesia terus menunjukkan peningkatan seiring dengan pertambahan jumlah penduduk dan pendapatan masyarakat (Marliah, 2012). Besarnya permintaan kedelai belum diimbangi dengan produksi kedelai di dalam negeri. Indonesia masih sangat bergantung pada Amerika Serikat (AS). Produksi dalam negeri yang belum mampu memenuhi kebutuhan menjadi salah satu alasan adanya kegiatan impor. Berdasarkan data Badan Pusat Statistik (BPS) yang dikutip, Jakarta (16/1/2019) kacang kedelai dari negeri Paman Sam masih sangat mendominasi dibandingkan dengan negara lainnya. Sepanjang 2018, dari total impor kacang kedelai yang sebesar 2,58 juta ton dengan nilai US\$ 1,10 miliar, kacang kedelai dari AS jumlahnya 2,52 juta ton dengan nilai US\$ 1,07 miliar (Hendra Kusuma, 2019).

Menurut Badan Pusat Statistik (2017), produksi kedelai secara nasional pada tahun 2017 sebanyak 538.728 ton, sangat jauh sekali mengalami penurunan dari tahun sebelumnya (2016) yaitu sebanyak 859.653 ton. Begitupun juga yang dialami di provinsi Bengkulu sangat jauh drastis mengalami penurunan. Dari tahun 2016 produksi kedelai di Bengkulu sebanyak 4.664 ton, di tahun 2017 produksi kedelai di Bengkulu hanya mencapai 413 ton. Hal ini disebabkan adanya penurunan produksi kedelai di beberapa wilayah di provinsi Bengkulu tepatnya di daerah Kabupaten Muko-Muko, Kaur, Rejang Lebong, Bengkulu Selatan dan Seluma (Antara Bengkulu, 2019). Untuk dapat memenuhi kebutuhan kedelai, Bengkulu mengandalkan impor dari luar provinsi seperti provinsi Lampung yang dimana produksi kedelai di provinsi Lampung lebih besar dari Bengkulu, yakni sebanyak 9.960 ton (2016).

Produksi yang rendah salah satunya disebabkan oleh benih yang kurang bermutu sehingga petani harus mendapatkan benih yang bermutu agar mutu kedelai yang baik ditentukan waktu panen yang tepat pemanenan berdasarkan dengan kriteria panen, namun ini tidak bisa dijadikan acuan atau pedoman karena tinggi tempat mempengaruhi umur panen (Pratama, 2018).

Salah satu usaha untuk mendapatkan hasil yang bermutu pemanenan harus dilakukan pada tingkat kematangan tertentu. Waktu panen pada umumnya ditentukan dengan cara menghitung umur tanaman atau lebih dikenal dengan metode satuan hari. Pada metode ini, penentuan umur panen dengan menghitung hari sulit dijadikan patokan karena di lapangan umur suatu genotip tanaman dapat berbeda sehubungan dengan tempat penanaman dan faktor lingkungan terutama suhu harian. Untuk menduga pematangan, pertumbuhan, hasil dan mutu benih tanaman kedelai lebih akurat digunakan metode satuan panas dibandingkan metode satuan hari. Metode tersebut tidak saja dapat menentukan saat matang tetapi juga dapat menentukan umur dan saat panen yang dapat digunakan berdasarkan pendekatan secara klimatologi dan agronomi sehingga kerusakan dan rasa dapat dihindari dan nantinya akan mendapatkan kualitas kacang kedelai yang baik (Podesta, Yawahar, dan Nofis, 2018)

Menurut Podesta (1997), masukan energi jumlah panas 1230-1250 satuan panas (sp) 124-125 hari sangat mempengaruhi terhadap bobot biji per tanaman, sedangkan masukan energi jumlah panas 1330-1350 sp 136-138 hari berpengaruh terhadap mutu benih dan pada masukan energi jumlah panas 1330-1350 sp 136-138 hari berpengaruh pada kualitas gizi kacang kedelai. Dan menurut penelitian Pratama (2018), masukan energi jumlah panas 1030-1050 sp berpengaruh nyata terhadap berat basah tanaman, berat polong basah, dan berat biji kering.

Selain penentuan masa panen yang kurang tepat masalah selanjutnya yang sama pentingnya yaitu kehilangan unsur hara dari dalam tanah dalam bentuk penghanyutan hara (erosi) dan pencucian unsur-unsur hara. Usaha untuk melestarikan kesuburan tanah ialah dengan penambahan yang disebut dengan pupuk. Di Indonesia pemakaian pupuk sangat cepat sejak diterapkan usaha intensifikasi pertanian untuk meningkatkan produksi bahan pangan, varietasvarietas unggul yang responsif terhadap pemupukan (Hasibuan, 2006).

Kesuburan tanah sangat berkaitan dengan sistem masukan energi jumlah panas (heat unit). 
Dimana kesuburan tanah ini mempengaruhi kematangan (panen). Pada tanah yang mengandung unsur fosfor $(\mathrm{P})$, tanaman akan cepat mengalami proses pembungaan, pemasakan buah dan biji sehingga akan mempercepat umur panen. Sedangkan pada tanah yang banyak mengandung unsur nitrogen $(\mathrm{N})$, tanaman akan mengalami pertumbuhan yang cepat terutama batang, cabang, dan daun. Namun, akan memperlambat proses pembungaan sehingga dapat memperlama umur panen. Begitupun dengan unsur kalium (K) yang juga sangat penting untuk memperkuat batang tanaman, daun, cabang, dan mencegah agar bunga dan buah tidak mudah gugur (Dewanti, 2014).

Berdasarkan uraian diatas, maka perlu dilakukan penelitian "Respon Tanaman Kedelai (Glycine max L. Merril) Terhadap Pupuk Anorganik Pada Berbagai Masukan Energi Jumlah Panas.

\section{BAB II}

\section{METODOLOGI PENELITIAN}

\subsection{Waktu dan Tempat Penelitian}

Percobaan dalam penelitian ini akan dilaksanakan selama 3 bulan dimulai dari bulan Juli 2019 sampai bulan Oktober 2019, di Jalan Danau Raya No. 59, Panorama, Singaran Pati, Kota Bengkulu Provinsi Bengkulu, pada ketinggian tempat kurang lebih $24 \mathrm{Mdpl}$.

\subsection{Alat dan Bahan}

Adapun alat-alat yang digunakan pada penelitian ini yaitu cangkul, sekop, timbangan, artco (klenteng/gerobak sorong), selang, ember, gayung, thermometer maksimum-minimum, kamera, dan alat tulis.

Adapun bahan-bahan yang digunakan pada penelitian ini yaitu tanah, pupuk kandang, polybag 10 $\mathrm{kg}$, benih kedelai Dena-1, furadan, rhizobium dan pupuk Anorganik (Urea, SP36, dan $\mathrm{KCl}$ ).

\subsection{Metodologi Penelitian}

Adapun penelitian ini dilaksanakan dengan menggunakan rancangan acak lengkap factorial (RAL). Terdiri dari 2 faktorial yaitu :

Faktor pertama yaitu Masukan Energi Jumlah Panas (MEJP) :

M1 $=1030-1050$ satuan panas (SP)

M2 $=1130-1150$ satuan panas (SP)

M3 $=1230-1250$ satuan panas (SP)

M4=1330-1350 satuan panas (SP)
Faktor kedua yaitu kombinasi pupuk Anorganik

$\mathrm{B} 1=12,5 \mathrm{~kg}$ Urea/ha $+100 \mathrm{~kg} \mathrm{SP}-36 / \mathrm{ha}+50 \mathrm{~kg}$ $\mathrm{KCl} / \mathrm{ha}$

$\mathrm{B} 2=25 \mathrm{~kg}$ Urea/ha $+50 \mathrm{~kg} \mathrm{SP}-36 / \mathrm{ha}+50 \mathrm{~kg} \mathrm{KCl} / \mathrm{ha}$

$\mathrm{B} 3=25 \mathrm{~kg}$ Urea/ha $+100 \mathrm{~kg}$ SP-36/ha $+25 \mathrm{~kg}$ $\mathrm{KCl} / \mathrm{ha}$

Terdapat 12 kombinasi perlakuan yaitu : M1B1, M1B2, M1B3, M2B1, M2B2, M2B3, M3B1, M3B2, M3B3, M4B1, M4B2, M4B3. Diulang sebanyak 3 kali ulangan sehingga terdapat 36 percobaan.

Hasil data yang di peroleh setelah di analisis secara statistik menggunakan analisis ragam dilanjutkan dengan uji Duncan's Multiple Range Test (DMRT) pada taraf $5 \%$.

\subsection{Pelaksanaan Penelitian}

\subsubsection{Persiapan Lahan}

Areal lahan dibersihkan dari sisa-sisa tumbuhan atau sampah-sampah sep rayu, batu, tunggul dan lain-lain.

\subsubsection{Media Tanam}

Pengambilan tanah dilakukan untuk mengisi polybag $10 \mathrm{~kg}$ yang sudah tersedia serta dilakukan pencampuran dengan pupuk kandang, yang bertujuan sebagai pupuk dasar untuk memperbaiki struktur tanah. Adapun perbandingan pupuk kandang dengan tanahnya yaitu $2: 1$, lalu media tanam dimasukkan ke dalam polybag sampai $2 / 3$ bagian.

\subsubsection{Persiapan Benih}

Benih yang digunakan dalam penelitian ini adalah benih kedelai varietas Dena 1 (Benih Sumber) yang didapatkan dari Balai Penelitian KacangKacangan Dan Umbi-Umbian (BALITKABI), Malang. Pertama-tama benih direndam dengan Rhizobium dengan dosis 10 gram per kilogram benih, lalu angkat dan anginkan hingga kering kemudian benih bisa langsung ditanam.

\subsubsection{Penanaman Benih}

Benih di tanam dalam lubang yang dibuat menggunakan tugal dengan kedalaman antara 1,5-2 $\mathrm{cm}$, setiap lubang tanam diisi sebanyak 2 biji pada setiap polybag.

\subsubsection{Pemeliharaan Tanaman}

a. Penyiraman

Penyiraman dilakukan sekali sehari pada sore hari, dengan cara menyiram seluruh tanaman dengan jumlah air yang sama rata. 


\section{b. Penjarangan}

Penjarangan dilakukan pada tanaman pada saat tanaman berumur satu minggu, tanaman yang di pilih adalah tanaman yang bagus, penjarangan ini dilakukan dengan memotong tanaman yang tidak perlu sehingga hanya satu tanaman yang paling baik pertumbuhannya.

\section{c. Penyulaman}

Penyulaman dilakukan maksimal 2 minggu setelah tanam, agar tidak terjadi perbedaan pertumbuhan yang terlalu mencolok antara tanaman asli dan hasil sulaman.

\section{d. Pemupukan}

Pemupukan dilakukan dengan cara tanah ditugal disamping lubang tanam (berjarak 3-5 cm), kemudian ditutup atau dibumbun. Untuk pemberian pupuk Urea dilakukan sebanyak 2 kali, yaitu pada saat penanaman dan pada saat kedelai mulai berbunga. Hal ini bertujuan untuk menghindari kehilangan $\mathrm{N}$ melalui penguapan (volatilisasi) ke udara yang dapat mencapai $60 \%$ dari pupuk yang diberikan. Sedangkan untuk pemberian pupuk SP36 dan $\mathrm{KCl}$ diberikan satu kali yaitu pada saat penanaman.

Secara umum, dosis pupuk yang direkomendasikan untuk pupuk Urea diberikan 25 $\mathrm{kg} / \mathrm{ha}$, pupuk SP36 diberikan $100 \mathrm{~kg} / \mathrm{ha}$, pupuk $\mathrm{KCl}$ diberikan $50 \mathrm{~kg} / \mathrm{ha}$ (Atman, 2014).

e. Perlindungan Tanaman dari Gulma, Hama dan Penyakit

Untuk menghindari persaingan antara gulma dan tanaman, maka dilakukan penyiangan. Penyiangan dilakukan setiap minggu saat terlihat gulma yang tumbuh di sekitar tanaman kedelai dengan cara mekanis, dengan cara dicabut menggunakan tangan.

Untuk pengendalian hama terutama belalang dan ulat dilakukan penyemprotan biopestisida dari daun serai.

\section{Pengamatan}

\section{Tinggi Tanaman $(\mathrm{cm})$}

Tinggi tanaman diukur dengan menggunakan mistar $(\mathrm{cm})$ dari permukaan tanah sampai ke titik apikal. Pengukuran dilakukan 2 minggu sekali.

\section{Jumlah Daun (helai)}

Daun kedelai termasuk daun majemuk, daun majemuk yaitu daun yang terdapat 3 daun dalam satu tangkai. Untuk menghitung jumlah daun kedelai ini, dihitung dari tangkai daun tersebut. Dan di lakukan 2 minggu sekali.

\section{Jumlah Cabang (cabang)}

Jumlah cabang tanaman dihitung pada setiap tanaman, di lakukan 2 minggu sekali.

\section{Berat Basah Tanaman (gr)}

Berat basah didapatkan dengan cara menimbang seluruh akar tanaman dengan menggunakan timbangan analitik (Digital Sartorius Bp 3100p) dilakukan pada akhir penelitian.

\section{Berat Kering Tanaman (gr)}

Berat kering tanaman ditimbang ketika sudah dijemur sampai berat konstan.

\section{Jumlah Polong (polong)}

Pengamatan dilakukan terhadap semua jumlah polong setiap tanaman sampel dengi enghitung jumlah polong yang berisi. Pengamatan $1 n$ dilakukan pada saat panen.

\section{Berat Polong Basah (gr)}

Pengamatan dilakukan terhadap semua berat polong basah setiap tanaman sampel dengan menimbang berat polong yang berisi. Pengamatan ini dilakukan pada saat panen.

\section{Berat Polong Kering (gr)}

Pengamatan dilakukan terhadap semua berat polong kering setiap tanaman sampel dengan menimbang berat polong yang berisi yang sudah kering. Pengamatan ini dilakukan pada saat panen.

\section{Jumlah Polong Cipo (polong)}

Dihitung saat sesudah panen, dengan cara memisahkan polong cipo dan bernas.

\section{Berat Biji Kering/Tanaman (gr)}

Pengamatan ini dilakukan pada saat kadar air $\pm 14 \%$. Untuk mencapai kadar air tersebut dilakukan dengan cara menjemur biji di bawah sinar matahari selama $2-3$ hari, kemudian ditimbang. Penimbangan biji dilakukan hanya pada tanaman sampel.

\section{Jumlah Biji/Tanaman (biji)}

Pengamatan ini dilakukan saat setelah panen, dengan cara menghitung jumlah seluruh biji/tanaman.

\section{Berat $100 \mathrm{Biji}$ (gr)}

Pengamatan ini dilakukan dengan cara menimbang 100 biji kedelai, dengan kadar air biji \pm $14 \%$ yang di peroleh dengan mengeringkan biji di bawah sinar matahari selama $2-3$ hari. 


\section{BAB III}

\section{HASIL DAN PEMBAHASAN}

\subsection{HASIL}

Hasil analisis keragaman untuk masingmasing faktor dan interaksinya terhadap semua parameter yang diamati yaitu tinggi tanaman, jumlah daun, jumlah cabang, berat basah tanaman, berat kering tanaman, jumlah polong/tanaman, jumlah polong cipo/tanaman, berat polong basah, berat polong kering, jumlah biji/tanaman, berat biji kering dan berat 100 biji, dapat dilihat pada tabel 2 .

Tabel 2. Hasil Sidik Ragam pengaruh masukan energi jumlah panas (MEJP) dan pupuk anorganik terhadap semua parameter yang di amati

\begin{tabular}{|c|c|c|c|c|c|}
\hline \multirow{2}{*}{\multicolumn{2}{|c|}{ Parameter yang diamati }} & \multicolumn{3}{|c|}{ F-hitung } & \multirow{2}{*}{$\begin{array}{l}\mathrm{KK}(\% \\
)\end{array}$} \\
\hline & & $\mathrm{M}$ & \multirow{2}{*}{$\begin{array}{c}\mathrm{B} \\
0.27\end{array}$} & \multirow{2}{*}{$\begin{array}{l}\text { MB } \\
0.29\end{array}$} & \\
\hline Tinggi & Tanaman 14 & 0.84 & & & \multirow{2}{*}{15,81} \\
\hline HST & & ns & ns & ns & \\
\hline Tinggi & Tanaman 28 & 2.19 & 1.11 & 1.23 & \multirow{2}{*}{10,12} \\
\hline HST & & ns & ns & ns & \\
\hline Tinggi & Tanaman & 0.68 & 1.28 & 1.16 & \multirow{2}{*}{19,34} \\
\hline HST & & ns & ns & ns & \\
\hline \multirow{2}{*}{\multicolumn{2}{|c|}{ Jumlah Daun 14 HST }} & 0.13 & $0.9 \mathrm{~ns}$ & 1.03 & \multirow{2}{*}{7,95} \\
\hline & & ns & & ns & \\
\hline \multirow{2}{*}{\multicolumn{2}{|c|}{ Jumlah Daun 28 HST }} & 1.08 & 0.29 & 0.69 & \multirow{2}{*}{22,16} \\
\hline & & ns & ns & ns & \\
\hline \multirow{2}{*}{\multicolumn{2}{|c|}{ Jumlah Daun 42 HST }} & 2.49 & 0.13 & 0.07 & \multirow{2}{*}{16,56} \\
\hline & & ns & ns & ns & \\
\hline \multirow{2}{*}{\multicolumn{2}{|c|}{ Jumlah Cabang 28 HST }} & 0.98 & 0.08 & 0.29 & \multirow{2}{*}{30,86} \\
\hline & & ns & ns & ns & \\
\hline \multirow{2}{*}{\multicolumn{2}{|c|}{ Jumlah Cabang 42 HST }} & 0.69 & 1,69 & 0.40 & \multirow{2}{*}{22,20} \\
\hline & & ns & ns & ns & \\
\hline \multirow{2}{*}{\multicolumn{2}{|c|}{ Berat Basah Tanaman }} & 1.49 & 0.43 & 1.88 & \multirow{2}{*}{18,40} \\
\hline & & ns & ns & ns & \\
\hline \multirow{2}{*}{\multicolumn{2}{|c|}{ Berat Kering Tanaman }} & 0.69 & 2,89 & $2,97 *$ & \multirow{2}{*}{17,74} \\
\hline & & ns & ns & & \\
\hline \multicolumn{2}{|c|}{ Jumlah } & 0.39 & $4,01 *$ & 1.33 & \multirow{2}{*}{16,22} \\
\hline \multicolumn{2}{|c|}{ Polong/Tanaman } & ns & & ns & \\
\hline Jumlah & Polong & 0.67 & 1.72 & 0.27 & \multirow{2}{*}{49,73} \\
\hline $\mathrm{Cipo} / \mathrm{Tr}$ & $\mathrm{mn}$ & ns & ns & & \\
\hline \multirow{2}{*}{\multicolumn{2}{|c|}{ Berat Polong Basah }} & 2.91 & 0.62 & & 20.73 \\
\hline & & ns & ns & ns & \\
\hline Berat $\mathrm{P}$ & long Kering & 2.76 & 0.46 & 0.46 & 2387 \\
\hline & & ns & ns & ns & 5 \\
\hline Jumlah & Biji/Tanaman & 0.35 & $4.62 *$ & & 1782 \\
\hline & & ns & & $\cdots$ & \\
\hline Berat & Biji & 2,76 & 0,99 & 0.58 & 2322 \\
\hline Kering/ & Tanaman & ns & ns & ns & \\
\hline Berat 1 & 0 Biji/Tanaman & 0.25 & 0.79 & 0.63 & 9,14 \\
\hline & & ns & ns & ns & 9,14 \\
\hline
\end{tabular}

\section{Keterangan}

M : Masukan Energi Jumlah Panas (MEJP)

B : Pupuk Anorganik

MB : Interaksi

ns : Non Signifikan (Tidak Berbeda Nyata)

* : : Berbeda Nyata
** : Sangat Berbeda Nyata

KK : Koefisien Keragaman

\subsection{PEMBAHASAN}

Respon tanaman kedelai (Glycine $\max L$. Merril) terhadap pupuk anorganik pada berbagai masukan energi jumlah panas.

Dari data hasil analisis ragam menunjukkan bahwa pupuk anorganik berpengaruh nyata terhadap jumlah polong per tanaman (tabel 8) dan jumlah biji per tanaman (tabel 12), tetapi tidak berpengaruh nyata terhadap tinggi tanaman (tabel 3), jumlah daun (tabel 4), jumlah cabang (tabel 5), berat basah tanaman (tabel 6), jumlah polong cipo per tanaman (tabel 9), berat polong basah (tabel 10), berat polong kering (tabel 11), berat biji kering (tabel 13), dan berat 100 biji (tabel 14). Sedangkan masukan energi jumlah panas tidak berpengaruh nyata terhadap semua pengamatan, dan terdapat interaksi antara kedua perlakuan antara masukan energi jumlah panas dengan pupuk anorganik terhadap berat kering tanaman (dapat dilihat pada tabel 7).

Hasil uji DMRT (Duncan's Multiple Range Test) menunjukkan bahwa perlakuan pupuk anorganik B2 $(25 \mathrm{~kg}$ Urea/Ha $+50 \mathrm{~kg} \mathrm{SP} 36 / \mathrm{Ha}+50$ $\mathrm{kg} \mathrm{KCl} / \mathrm{Ha}$ ) menunjukkan pengaruh yang nyata terhadap jumlah polong dan jumlah biji. Dengan jumlah polong tertinggi yaitu 135,62 polong, dan jumlah biji tertinggi yaitu 388,62 biji. Hal tersebut sejalan dengan hasil penelitian Suharjo (2001) dalam Nihayati, dkk (2018) dalam pengisian polong dan pembentukan biji sangat tergantung pada ketersediaan $\mathrm{N}$, baik $\mathrm{N}$ yang diambil oleh bakteri Rhizobium dari udara maupun $\mathrm{N}$ yang tersedia dalam tanah dan dipengaruhi juga oleh ketersediaan unsur P. Apabila ketersediaan $\mathrm{N}$ berada dalam kondisi seimbang akan mengakibatkan pembentukan asam amino dan protein meningkat dalam pembentukan biji sehingga polong terisi penuh. Selain itu Hanum (2010) dalam Nihayati, dkk (2018) yang menyatakan bahwa peningkatan nitrogen tanaman akan mempengaruhi laju serapan $\mathrm{P}$, dan berakibat pada laju pengisian biji , dimana diketahui tanaman membutuhkan unsur hara $\mathrm{N}$ dan $\mathrm{P}$ yang tinggi untuk pembentukan bijinya.

Hasil uji DMRT (Duncan's Multiple Range Test) menunjukkan bahwa terdapat interaksi antara masukan energi jumlah panas dengan pupuk anorganik terhadap berat kering tanaman yaitu pada masukan energi jumlah panas M4 (1330-1350 SP) dengan pupuk anorganik B1 $(12,5 \mathrm{~kg}$ Urea/Ha +100 $\mathrm{kg} \mathrm{SP36/Ha}+50 \mathrm{~kg} \mathrm{KCl} / \mathrm{Ha})$ menunjukkan nilai tertinggi sebesar 96,17 gram. Hal tersebut disebabkan oleh lamanya proses penyinaran matahari sampai pada tingkat 1330-1350 SP sehingga banyak cahaya yang diserap oleh tanaman dan kebutuhan unsur hara yang tercukupi mengakibatkan proses fotosintesis yang terjadi pada tanaman menjadi lebih efektif, 
apabila fotosintesis terjadi secara efektif maka fotosintat yang dihasilkan akan semakin besar pula. Hal tersebut sesuai dengan Gardner (1991) dalam bukunya yang menyatakan bahwa hasil berat kering total merupakan akibat efisiensi penyerapan dan pemanfaatan radiasi matahari yang tersedia sepanjang musim pertumbuhan oleh tajuk tanaman budidaya. Begitupun juga dengan Mulyadi (2012) dalam Nihayati, dkk (2018), ketersediaan P yang cukup bagi tanaman akan berpengaruh terhadap berat kering tanaman. Semakin tinggi ketersediaan $\mathrm{P}$ bagi tanaman maka transfer energi dan metabolisme tanaman akan semakin baik, berat kering tanaman yang dihasilkan juga semakin tinggi.

\section{BAB IV}

\section{KESIMPULAN}

\section{Kesimpulan}

Kesimpulan yang dapat diambil dari hasil penelitian ini:

1. Masukan Energi Jumlah Panas tidak berpengaruh nyata terhadap semua parameter pengamatan tanaman kedelai (Glycine max L. Merril)

2. Pupuk Anorganik berpengaruh nyata terhadap jumlah polong dan jumlah biji tanaman kedelai (Glycine max L. Merril).

3. Terjadi interaksi antara perlakuan Masukan Energi Jumlah Panas dengan Pupuk Anorganik terhadap berat kering tanaman kedelai (Glycine $\max \mathrm{L}$. Merril).

\section{DAFTAR PUSTAKA}

Adisarwanto. 2014. Budidaya Kedelai Tropika. Penebar Swadaya. Jakarta.

Amanda, Rianti. 2008. Meraup Untung Dengan Palawija. Penerbit : CV. Pringgandani. Jl. Pasar Kaler, Pandalarang-Kab. Bandung Barat. Bandung.

Atman. 2014. Strategi Meningkatkan Produksi Kedelai Melalui PTT. Graha Ilmu. Yogyakarta BPS (Badan Pusat Statistik). 2017. Impor Kedelai Menurut Negara Asal Utama 2014-2018. Ekspor-Impor.

Cahyono B. 2007. Kedelai. CV Aneka Ilmu. Semarang.

Departemen Ilmu Dan Teknologi Pangan. Fakultas Pertanian. Institut Pertanian Bogor. https://fateta.ipb.ac.id/organisasi-departemenitp/. Diakses 27 Maret 2019 pukul 13:22.
F, Deru dewanti. 2014. Pengaruh Suhu Terhadap Pertumbuhan Dan Produksi Tanaman. https://dokumen.tips/documents/bahan-jarsuhu.html. Diakses pada 09 Maret 2019, pukul 20:20

Firmanto, B.H. 2011. Praktis Bercocok Tanam Kedelai Secara Intensif. Penerbit Angkasa. Bandung

Goenadi DH. 2006. Pupuk Dan Teknologi Pemupukan Berbasis Hayati Dari Cawan Petri Ke Lahan Petani Edisi Pertama. Yayasan John Hi-Tech Idetama. Jakarta.

Hasibuan, BE. 2006. Pupuk Dan Pemupukan. Fakultas Pertanian. Universitas Sumatra Utara, Medan, Hal. 175.

Herdiyantoro D, 2013. Rancangan Acak Faktorial Acak Lengkap dan Acak Kelompok. Fakultas Pertanian Universitas Padjadjaran.

PT. Manohara Asri. 2018. Http://manoharaasri.com/id/articles/detail/benarkah-proteinkacang-tanah-lebih-tinggi-dari-daging-yuksimak. Diakses 09 Maret 2019 pukul 20.00.

Antara Bengkulu. 2019.

Http://sp.beritasatu.com/home/2000-ton-

kedelai-impor-belum-sampai bengkulu/42155.

Diakses 09 Maret 2019 pukul 20.15

Hendra Kusuma. 2019. Detik Finance. https://finance.detik.com/berita-ekonomibisnis/d-4387112/25-juta-ton-kedelai-asmasuk-ri-sepanjang-2018. Diakses pada 06 April 2019, pukul 18:10

BPS.

https://www.l__o.id/statictable/2019/02/14/

2015/impor-kedelai-menurut-negara-asalutama-2010-2017.html. Diakses 09 Maret 2019, pukul 20:21

Kementerian Pertanian Republik Indonesia. 20142018. Produksi Kedelai. Diakses pada 09 Maret 2019 pukul 20.20

Kurniawan Shandy, Rasyad Aslim, Wardati. 2014. Pengaruh Pemberian Pupuk Posfor Terhadap Pertumbuhan Beberapa Varietas Kedelai (Glycine max (L.) Merril). Jom Faperta Vol. 1 No. 2.

Lingga, Marsono. 2004. Petunjuk Penggunaan Pupuk. Redaksi Agromedia. Jakarta.

Marliah A, Hidayat T, Husna N. 2012. Pengaruh Varietas Dan Jarak Tanam Terhadap Pertumbuhan Kedelai (Glycine max (L.) Merril). Jurnal Agrista (1) : 22-28.

Nurdin, P. Maspeke, Z. Ilahude, F. Zakaria. 2008. Pertumbuhan dan Hasil Jagung yang Dipupuk N, P, dan K Pada Tanah Vertisol Isimu Utara Kabupaten Gorontalo. Universitas Negeri Gorontalo, Gorontalo. 14 (1) : 49-56. 
Podesta Fiana, Yawahar Jon, Nofis Iskan. 2018.

Pengaruh Masukan Energi Jumlah Panas Dan

Pemangkasan Terhadap Pertumbuhan Dan

Hasil Kacang Tanah (Arachis hypogeae L.).

Podesta P. 1997. Masukan Energi Jumlah Panas Dan

Konsentrasi 2,4-D Terhadap Hasil, Mutu

Benih dan Kualitas Gizi Kedelai (Glycine max

(L.) Merril). Program Pascasarjana.

Universitas Andalas Padang.

Podesta, F. 2007. Seri Budidaya Tanaman Kedelai.

Universitas IBA Palembang. Palembang.

Pracaya, Kahono P.C. 2010. Kiat Sukses Budidaya

Palawija. Klaten : PT. Macanan Jaya

Cemerlang.

Pratama Dorizky. 2018. Masukan Jumlah Energi Panas Dan Macam-Macam Bioaktivator Darah Sapi Terhadap Pertumbuhan Dan Hasil Kacang Kedelai (Glycine max L. Merril).

Rauf, A.W., T. Syamsuddin, S.R. Sihombing. 2000. Peranan Pupuk NPK Pada Tanaman Padi. Loka Pengkajian Teknologi Pertanian.

Ridwan Nurul Annisa, Hidayat Kuswanta F, Kushendarto, Sunyoto. 2017. Pengaruh Dosis Pupuk Majemuk NPK Dan Pupuk Pelengkap Plant Catalyst Terhadap Pertumbuhan Dan Produksi Kedelai (Glycine max (L.) Merril). Jurnal Agrotek Tropika Vol. 5 No. 1 Hal. 1-6.

Suhaeni N. 2007. Petunjuk Praktis Menanam Kedelai. Nuansa. Bandung.

Sumarno, G. Mansyuri. 2007. Persyaratan Tumbuh dan Wilayah Produksi Kedelai di Indonesia. Hlm. 74-103. Dalam, Sumarno, Suyamto, A. Widjono, Hermanto dan H. Kasim. (Ed) Kedelai. Teknik Produksi dan Pengembangan. Pusat Penelitian dan Pengembangan Tanaman Pangan, Bogor.

Suprapti, M. 2005. Kedelai Tradisional. Kanisius. Jogjakarta.

Suprapto, HS. 1999. Bertanam Kedelai, PT. Penebar Swadaya. Jakarta

Susanto, dan T.Sundari. 2011. Perubahan karakter agronomi aksesi plasma nutfah kedelai di lingkungan ternaungi. Jurnal Agronomi Indonesia, 39(1): 1-6

Winarsi. 2010. Tinjauan Pustaka Kedelai. Http://digilib.unila.ac.id/1308/8/BAB\%20II.pd

f. Diakses pada 09 Maret 2019 pukul 20.00.

Winarso S. 2005. Kesuburan Tanah dasar Kesehatan Dan Kualitas Tanah. Edisi Pertama. Gava Media. Yogyakarta. 